\title{
SMART-SPECIALIZATION OF REGION AND SUBREGION AS TOOL TO ENSURE CONSUMPTION SAFETY
}

\author{
Kateryna Antoniuk1 ${ }^{1}$, Anatoly Mokiy², Dmytro Antoniuk ${ }^{3}$ \\ ${ }^{1}$ National University "Zaporizhzhya Polytechnic” (Ukraine) \\ Department of International Economic Relations \\ ${ }^{2}$ SI «M.I. Dolishny Institute of Regional Research NAS of Ukraine» (Ukraine) \\ Department of Regional Economic Policy \\ ${ }^{3}$ Zaporizhzhya National University (Ukraine) \\ Department of Entrepreneurship, Management and Logistics
}

\begin{abstract}
The aim of the article was to study regional innovative development through the implementation of projects and programs of subregional smart specialization to strengthen consumption safety. To ensure the conceptual integrity of the study, such methods as theoretical generalization, comparison, dialectics, analysis and systematization, institutional analysis, statistical analysis and the smart specialization approach to innovative regional development were used. As a result of the conducted research, an inextricable relationship was established between consumption safety and regional innovative development. The state, problems and prospects of innovative development and smart specialization are studied on the example of the Zaporizhzhia region (in Ukraine), which as an "old industrial" one with a number of environmental problems and corresponding negative consequences for public health, has significant threats to consumption safety. It was found that the application of a sectoral approach to smart specialization will create conditions to position regional producers and products as resource- and environmentally friendly, which will strengthen competitiveness, increase enterprise income, reduce their environmental impact and raise the quality of life of the region. The importance of sectoral and subregional smart specialization (at the level of united territorial communities, urban areas, rural settlements) to strengthen consumption safety is substantiated.
\end{abstract}

Keywords: consumption safety, innovation potential of the region, smart specialization, subregion

DOI: $10.17512 /$ znpcz.2021.3.01

\section{Introduction}

Strengthening consumption safety should take place at all levels of the system hierarchy (state, regional, local). State-level measures are mainly related to the implementation of strategic priorities, improvement of the institutional base, and modernization of state policy to ensure consumption. At the regional level, ensuring consumption safety is largely determined by the socio-economic development of the region or community, the level of education and wages, quality of life, as well as the

\footnotetext{
${ }^{1}$ Kateryna Antoniuk, Associate professor, Dr of Economics, ekaterinaia@ukr.net, ORCID: 0000-00018568-5085

2 Anatoly Mokiy, Senior researcher, Dr of Economics, amokiy320@ukr.net, ORCID: 0000-00018455-1421

${ }^{3}$ Dmytro Antoniuk, Professor, Dr of Economics, oasdant@gmail.com, ORCID: 0000-0003-2910-0497
} 
availability of innovative enterprises. All this forms the innovative potential of the region, which is important to ensure consumption safety because introducing changes in the technological processes of production and ensuring the safety characteristics of goods (services) is based on innovative development. The main reason for the low level of innovation activity is that it is rather difficult to unite the main components of the national innovation system - business, science, education and the state.

The innovative development of regions is determined by the interaction of three components: the presence of state support, the participation of large enterprises, in addition to the involvement of small businesses. At the same time, the intensification of innovation activity in the region requires close interaction with the external environment. The obstacle to innovation development is often not so much underdevelopment of the innovation infrastructure and the lack of investment, as insufficient development of the marketing information system and the use of tools to study the economic activities of leading industries, and the lack of connection with foreign markets, especially for small and medium-sized enterprises. In the context of consumption safety, it is important to prioritize smart specialization for innovative development and use limited resources to achieve specific goals.

Some theoretical and applied aspects of the smart-specialization concept are presented in the works of domestic and European researchers, in particular J. Bjuska, J. Pika (Brzóska, Pyka 2012), P. David, D. Forey, B. Hall (Foray, David, Hall 2009), M. Kardas (Kardas 2011), G. Tobor (Tobor 2012) and others. Nonetheless, systematic studies of the impact of smart-specialization on regional innovative development and the strengthening of consumption safety have not been conducted.

\section{Methods}

The fundamental basics of the theory of a global, national economy, innovative economy, regionalism, economic and consumption safety make the theoretical and methodological basis of the study. To ensure the conceptual integrity of the study, such methods as theoretical generalization, comparison, dialectics, analysis and systematization, institutional analysis, statistical analysis and the smart specialization approach to innovative regional development were used. The official statistics of the EU and Ukraine for 2013-2020 were analysed.

\section{Results}

\section{Analysis of innovation potential of Zaporizhzhia region in context of strengthening consumption safety}

We will survey the implementation of smart specialization projects on the example of the Zaporizhzhia region as an "old-industrial" region with a number of acute environmental problems and the corresponding negative consequences for public health, which are significant threats to consumption safety. In the region over the past decades, there has been a gradual decrease in the number of research organizations and their staff due to insufficient funding and lack of motivational mechanisms to attract scientists, and most importantly, young professionals to research. 
The Zaporizhzhia region is a part of the group of regions of Ukraine that form the basis of the economic and intellectual potential of the country. Almost all major industries are concentrated here, of which the most significant are the electricity, metallurgy, mechanical engineering, metalworking and chemical industry. The Zaporizhzhia region is characterized by a high level of innovation potential.

However, the analysis shows that during 2013-2018, there was a significant decrease in innovation activity of industrial enterprises in the region: if in 2013 this figure was $28.8 \%$ of the total number of industrial enterprises in the region, in 2020 it was less than $19 \%$. Hence, in 2020 only one in five companies was innovative, in 2013 - one in three (Strategy of Regional... 2019).

Despite the decrease in the number of enterprises that implemented innovations during 2013-2019, the volume of sold innovative products increased from 1671.1 million UAH to 4041.2 million UAH (2.4 times). In terms of the volume of sold innovative products, the region ranked first in 2019 , which amounted to $22.8 \%$ of the total volume of sold innovative products in Ukraine.

We consider the low share of innovative products in the volume of sold products of the region to be negative (2.3-2.4\%). The volume of fundamentally new innovative products also remains insignificant, which confirms that industrial enterprises sell innovative products, the production of which is new only for the enterprise, but not for the market.

The growth of the output of innovative products is due to an increase in the costs of enterprises for innovation - 4.7 times during 2013-2018, against the background of their decline in Ukraine as a whole by $4.7 \%$. The region accounted for $15.3 \%$ of the total funding for innovation in Ukraine.

The agricultural, industrial, including machine-building specialization of the Zaporizhzhia region contributes to the fact that $88.6 \%$ of research and development in priority areas of science and technology are the latest and resource-saving technologies in energy, industry and the agro-industrial complex. In addition, new technologies are introduced during the design and construction of agricultural, metallurgical, and high-tech engineering facilities.

Analysis of the sources of financing innovative activity shows that the majority of scientific works are carried out with funds of the enterprises themselves; investments are more often laid out for scientific and technical development, while the financing of basic scientific research is insignificant.

The most active innovations are in machine-building enterprises and the sphere of information technology. The dynamics of implementing new technologies is generally unstable, but positive, which may be explained by the complexity of mechanical engineering, as we showed in (Antoniuk, Antoniuk 2012).

\section{Problems of innovative development of old industrial regions}

In the economic activity of enterprises involved in the development of innovative products, there are a number of problems (as shown Nazarenko 2007, p. 19) that can be projected onto other old industrial regions, and in general on the domestic economy. Among these problems is the lack of own funds, a flawed legal framework, 
low effective demand for new products, unpreparedness for innovation and new technologies, high risk, lack of information about new technologies, markets, significant costs of innovation and the long payback period, as well as the lack of demand for innovative products.

There is a significant flaw in the mechanism of interaction between consumers and producers of innovative products, despite the fact that there is an active market for innovation and intellectual products both in Ukraine and abroad. The reason for this is the lack of an institutional infrastructure that would allow the results of R\&D to be transformed into technology and new products. Taking into account the international experience in the Zaporizhzhia region, this problem should be solved through the development of an innovation and information infrastructure of entrepreneurship such as business cooperation bureaus, chambers of commerce and industry, business incubators, framework programs, in addition to consulting companies.

\section{Implementation of smart specialization strategies at regional level}

In the context of further development and effective use of innovation potential as a necessary prerequisite for strengthening economic security at various levels of the management hierarchy, including consumption safety, it is advisable to develop smart specialization strategies to identify and implement economic growth potential, unique for each object of specialization, based on its specific competitive advantages (Shevchenko 2019). According to the analytical results of our study, we consider it necessary to expand the object of specialization to the economic sector of its subregion. This approach aims to stimulate innovation through the harmonization of interests, integration of the resource potential and competencies of participants (local authorities, researchers, businesses and civilians) and allows the development goals of industrial and agricultural enterprises to be aligned with Sustainable Development Goals. In this context, smart specialization strategies are to create the conditions for socio-economic management to transform needs using strengths and competitive advantages into consumption-friendly goods (services). Objects (sectors, industries, regions, subregions, cities) of specialization are determined on the basis of analysis of the dynamics and development trends of regional economy closely related to regional clusters, the development of which is based on methods of calculating localization coefficients.

Smart strategies are an integral part of the European concept of innovation development and an instrument of regional innovation policy. To spread the positive experience, the European Commission created a Smart Specialization Platform in 2011, which brings together the regions of the EU and other countries, providing them with advisory, information-analytical and other types of support. Regions of Ukraine (Kharkiv, Cherkasy, Chernihiv and Zakarpattia regions) also joined the Platform, focusing on key and important priorities to strengthen consumption safety as well as resource-efficient technologies and alternative energy, the development of environmentally friendly production technologies, the production of new materials and nanotechnologies, etc.

The institutional basis of this process in Ukraine is formed by the provisions of the Law of Ukraine "On Scientific and Scientific-Technical Activity" of 26.11.2015 
№ 848-VIII, the Cabinet of Ministers' Resolution “On approval of the Procedure for developing the State Strategy of Regional Development of Ukraine and action plan for its implementation, monitoring and evaluation of the effectiveness of the implementation of these Strategies and Action Plan". We should note that to date this strategy has not been developed and approved.

The main partners in the implementation of smart specialization in Ukraine are the Directorate General of the European Commission and its Joint Research Centre (JRC), which has developed a methodology for smart specialization in the EU and beyond. Three pilot regions (Kharkiv, Odesa and Zaporizhzhia oblasts) were selected for its implementation in Ukraine, the Cherkasy and Zakarpattia oblasts were included in the second phase of the project. However, there is currently no information on the implementation of these programs and projects. Access to EU financial and technical support (Horizon 2020, COSME) will be opened to regions that have decided on their smart specialization and have received confirmation from the European Commission. Thus, the areas of specialization in the Kharkiv region are: high value-added production, bioeconomics and agricultural technologies, education of the future, Smart-IT solutions; in the Rivne region - woodworking and furniture industries, processing of agricultural raw materials, organic agriculture, berry and gardening, logistics, and the IT sector (Shevchenko 2019).

In the Zaporizhzhia region, experts of the JRC and SI "M.I. Dolishny Institute of Regional Studies" within the Zaporizhzhia Region Development Strategy until 2027, identified a list of activities as the basis for smart specialization (Strategy of Regional... 2019). They included the production of endoprostheses from molybdenum and titanium materials; the manufacture of electric motors, generators, transformers, electrical distribution and control equipment, wires, cables and electrical devices; the manufacture of machinery and equipment for agriculture and forestry, engines and spare parts for propellers. These activities are characterized by significant dynamics in the share of employees and can stimulate the growth of output in related industries and economic activities. It is necessary to ensure the production of goods for these activities, taking into account the principles of consumption safety, including protection of the environment and human health. In the field of agricultural engineering, it is important to introduce technological production processes with a reduced negative impact of finished products on soils and to minimize the share of post-harvest waste. All this should be understood by all participants in the process of product design, production and sale, in accordance with the strategy of smart specialization of the region. The application of a sectoral approach to smart specialization will create the preconditions for positioning regional producers and products as resource- and environmentally friendly, which will strengthen competitiveness, increase enterprise income, reduce the negative impact on the environment and increase the quality of life in the region.

\section{Subregional smart specialization to strengthen consumption safety}

In addition to regional smart specialization, sectoral and subregional smart specialization is important to raise the quality of life and competitiveness in the global dimension, additionally at the level of united territorial communities, urban areas, 
and rural settlements. The significant obstacles to the implementation of smart specialization are associated with limited human, intellectual, financial resources, and a lack of sufficient statistics required for the first stage of strategic programming. Nonetheless, it is advisable to conduct smart specialization in local areas when there are organizations that can create innovative products and solutions or to revitalize and recover old industries and subregions. After that, other, less developed territories should be involved in smart specialization on the basis of inclusiveness.

The impact of sectoral and subregional smart specialization on strengthening consumption safety will be considered on the example of the Dnieper district of Zaporizhzhia, the intensive development of which, like the whole city, began in the 1920 s with construction of the Dnieper hydroelectric power plant, the most powerful one at that time in Europe. The main types of industrial activity in the area are manufacturing, the production and distribution of electricity, electrical engineering, construction and transport. In recent years the economic situation of enterprises of a powerful electrical cluster formed in the Dnieper region has deteriorated significantly due to the loss of competitiveness of products compared to global counterparts. To some extent, this was facilitated by the limited export to European countries after conclusion of the Association Agreement between Ukraine and the EU owing to the lack of conformity assessment and certification in Ukraine as well as significant time and money spent in European institutions. As a result, the level of tax revenues, social contributions, quality of life, and consequently, consumption safety has decreased significantly.

Despite this, the district has a well-developed network of educational institutions (19 preschools, 2 preschool departments, 21 secondary schools, 3 secondary technical and vocational schools, 2 universities), which has a positive trend of development and renewal. The scientific and technological design potential of the subregion is represented by: the Zaporizhia Medical Academy of Postgraduate Education; JSC Ukrainian Research Institute "VIT"; Zaporizhzhya Institute of Economics and Information Technologies; PJSC CB "Zaporizhhydrostal". To provide residents of the district with qualified, affordable and high-quality medical care, the network of treatment and prevention facilities is stable and well-established. There are objects of culture and art in the district, the main purpose of which is to promote the spiritual development of residents through cultural, artistic and educational work, to form the national identity and create conditions for creative potential and new initiatives.

Analysis of the socio-economic development allows us to conclude that the sociopolitical situation in the area is stable and predictable in spite of the negative trends in the work of enterprises.

To diversify the economy of the subregion on the basis of inclusive development and smart specialization, it is urgent to develop the institutional infrastructure of entrepreneurship, consulting and training clusters because despite having a well-developed structure of design bureaus and plants, the area is deprived of a unifying core, technology or innovation park and the ability to use modern expert-technical, certification, and laboratory services that meet EU requirements. Technology transfer tools (technology exchange offices between universities, technology brokers in research centres, etc.) need active development. 
The greatest impact on the economy of the subregion may be the focus on the restoration of the following smart specializations:

- high-precision electrical enterprises that have prospects for further development, including the introduction of new information technologies, changes in approaches to the organization of activities and expanding cooperation with foreign and domestic partners;

- high-precision design research - companies and bureaus that demonstrate a high level of innovation and patent-inventive activity in addition to scientific and technical potential with a low level of cooperation with scientific and educational institutions from European countries. Note that the enterprises of the subregion have highly specialized markets (military-industrial complex, medical equipment, aviation), the development of which requires primarily state rather than regional policy support.

The implementation of the subregional smart specialization project can lay the foundation for the development of the Dnipro district, and will help to reduce the level of divergence compared to neighbouring subregions. Note that the further divergence of the economies of Ukraine and the EU detected by T. Burlay after conclusion of the Association Agreement, according to A. Mokiy et al. (2020), is manifested in the national socio-economic macrosystem at different levels of vertical and horizontal hierarchy. Moreover, the divergence is exacerbated by exclusivity and the resulting dysfunction of governance according to O. Sukharev (2015), as well as the institutional flaws of public administration.

Given the above, the conceptual foundations of the strategy of subregional smart specialization can be formulated as follows.

First of all, it is about the focus of projects on eliminating threats to consumption safety, mitigating problems of the divergence of national and regional economies.

Secondly, it is important to coordinate projects with other inefficient forms of the inclusive growth model - public-private partnership projects, cluster organization of production and sales, as well as cooperative movement.

Third, let us agree with D. Oliynyk that assimilation is needed in the process of developing and implementing draft ISO standards "Smart Community Infrastructure".

Fourth, at all stages of project development and implementation, especially preproject, a methodological basis is needed. This we consider through the provisions of the Other Kaonon E. Reinert (Reinert 2008) for the choice of activities and increasing returns, reducing costs, in addition to the synergistic effect of scientific and technological activity.

\section{Conclusions}

According to the research results, the innovation potential of the region is important to strengthen consumption safety. This can be explained by the fact that the introduction of changes in technological processes of production and ensuring the safety characteristics of goods (services) is based on innovative development. 
On the example of the Zaporizhzhya region (in Ukraine) as an "old-industrial" region, its powerful potential (due to the number of educational institutions, research organizations, strong branches of specialization) was studied and significant obstacles to innovative development were identified (such as the lack of business skills of researchers, the isolation of education and R\&D from practical business needs, an underdeveloped innovation culture, the lack of a culture of investing in innovation development, low efficiency of financial assistance from the state due to the unstable political and economic situation in addition to the flaws of institutional support for innovation development).

The European experience of regional policy allowed the advanced approach to development of the region to be offered on the basis of smart specialization (through the direction of a limited number of resources and types of economic activity), cluster formations and an increase in innovative attractiveness of territories. It was established that the application of a sectoral approach to smart specialization will create prerequisites for positioning regional producers and products as resource- and environmentally friendly, which will strengthen their competitiveness, increase enterprise income, reduce their environmental impact and raise the quality of life of the region.

The importance of sectoral and subregional smart specialization (at the level of united territorial communities, urban areas, rural settlements) to strengthen consumption safety is substantiated. To diversify the economy of the subregion on the basis of inclusive development and smart specialization, the approach was tested on the example of a separate Dniprovskiy district of Zaporizhzhya with the identification of key areas of development such as high-precision electrical enterprises and high-precision design research.

\section{References}

1. Antoniuk K.I., Antoniuk D.A. (2012), Problems and Prospects of Innovative Development of the Industrial Region (on the Example of Zaporozhye Region), Economic Bulletin of the National Technical University of Ukraine "Kyiv Polytechnic Institute": Coll. Science. wash. K.: NTUU "KPI", Vol. 9, pp. 397-403 [in Ukrainian].

2. Brzóska J., Pyka J. (2012), Rozwój ekosystemu innowacji w Regionie w perspektywie 2020 roku, [in:] Pyka J. (red.), Nowoczesność przemystu i ustug - nowe wyzwania, TNOiK, Katowice [in Polish].

3. Foray D., David P., Hall B. (2009), Smart Specialisation - The Concept, "Knowledge Economists Policy Brief', Vol. 9(85), p. 100.

4. Kardas M. (2011), Inteligentna specjalizacja - (nowa) koncepcja polityki innowacyjnej, „Optimum. Studia Ekonomiczne”, Vol. 2, WSE, Białystok.

5. Mokiy A.I., Sklyar N.M., Pikh M.Z., Bubley G.A. (2020), Trade Partnership of Ukraine from the Position of "Another Canon" by E. Reinert, http://ief.org.ua/docs/scc/14.pdf (accessed: 15.06.2021) [in Ukrainian].

6. Nazarenko V.A. (2007), Research of Investment and Innovation Priority of Development of Zaporozhye Region, Regional Rescue and Development Project, Zaporozhye [in Ukrainian].

7. Reinert E. (2008), How Rich Countries Got Rich ... and Why Poor Countries Stay Poor, PublicAffairs, New York. 
8. Shevchenko A.V. (2019), Strategic Priorities for the Introduction of Smart Specialization in Ukrainian Industry, "Business Inform”, Vol. 10, pp. 130-135 [in Ukrainian]. DOI: 10.32983/22224459-2019-10-130-135.

9. Strategy of Regional Development of Zaporizhia Region for the Period Up to 2027 (2019), https://www.zoda.gov.ua/files/WP_Article_File/original/000130/130216.pdf (accessed: 15.06.2021) [in Ukrainian].

10. Sukharev O.S. (2015), Conditions, Dynamics and Strategies Of Industrialization: How Important the Structure of Technologies Is to Us, https://inecon.org/docs/Sukharev_VEO_2015_3.pdf (accessed: 15.06.2021) [in Ukrainian].

11. Tobor G. (2012), Smart specialisation a rozwój aglomeracji górnoślaskiej, [in:] Pyka J. (red.), Nowoczesność przemystu i ustug - nowe wyzwania, TNOiK, Katowice [in Polish].

\title{
SMART SPECJALIZACJA REGIONU I PODREGIONU JAKO NARZĘDZIE ZAPEWNIAJĄCE BEZPIECZEŃSTWO KONSUMPCJI
}

\begin{abstract}
Streszczenie: Celem artykułu jest badanie regionalnego rozwoju innowacyjnego poprzez realizację projektów i programów subregionalnych inteligentnych specjalizacji wzmacniających bezpieczeństwo konsumpcji. W celu zapewnienia integralności pojęciowej badania zastosowano takie metody jak uogólnienie teoretyczne, porównanie, dialektyka, analiza i systematyzacja, analiza instytucjonalna, analiza statystyczna oraz podejście inteligentnej specjalizacji do innowacyjnego rozwoju regionalnego. W wyniku przeprowadzonych badań ustalono nierozerwalny związek między bezpieczeństwem konsumpcji a regionalnym rozwojem innowacyjnym. Stan, problemy i perspektywy rozwoju innowacyjnego i inteligentnej specjalizacji badane są na przykładzie regionu Zaporoża (na Ukrainie), który jako „stary przemysłowy” z wieloma problemami środowiskowymi i odpowiadającymi im negatywnymi konsekwencjami dla zdrowia publicznego dotknięty jest istotnymi zagrożeniami dla bezpieczeństwa konsumpcji. Stwierdzono, że zastosowanie sektorowego podejścia do inteligentnej specjalizacji stworzy warunki do pozycjonowania regionalnych producentów i produktów jako przyjaznych dla zasobów i środowiska, co wzmocni konkurencyjność, zwiększy dochody przedsiębiorstw, zmniejszy wpływ na środowisko i podniesie jakość życia regionu. Uzasadnione jest znaczenie sektorowej i subregionalnej inteligentnej specjalizacji (na poziomie zjednoczonych wspólnot terytorialnych, obszarów miejskich, osiedli wiejskich) dla wzmocnienia bezpieczeństwa konsumpcji.
\end{abstract}

Słowa kluczowe: bezpieczeństwo konsumpcji, potencjał innowacyjny regionu, smart specjalizacja, podregion 